В. А. Белозорович

Гродненский государственный университет имени Янки Купалы

\section{БОРЬБА С НАЦИОНАЛ-ДЕМОКРАТИЧЕСКИМ ТЕЧЕНИЕМ В БЕЛОРУССКОЙ ИСТОРИОГРАФИИ}

В статье раскрывается процесс утверждения марксистско-ленинской методологии в исторической науке БССР в 1920-е -1930-е гг. под влиянием общественно-политических изменений в советском обществе. Проведен историографический анализ научных работ, подготовленных национально-ориентированными белорусскими историками. Показана роль Института истории партии и Октябрьской революции при ЦК КП(б)Б как методологического центра по борьбе за «чистоту» исторических взглядов. Раскрыт отход ряда исследователей, в частности А. Г. Червякова, Д. Ф. Жилуновича, от национальных позиций в оценке истории Беларуси.

Исследование базируется на историографических источниках литературного характера, представленных в форме книжной продукции и публикаций в периодических изданиях. Среди них - работы И. Ю. Лёсика, А. Л. Бурбиса, Ф. Ф. Турука, П. В. Тремповича, С. Я. Вольфсона, Д. М. Василевского и др. Также изучена научно-популярная литература идейной направленности - публикации С. Х. Агурского, А. И. Столевича, А. А. Сенкевича и др.

Сделан вывод о радикальной смене методологической парадигмы в историческом познании, проявившейся в переходе от исследовательского плюрализма 1920-х пг. к единомыслию 1930-х гг.

Ключевые слова: историография, национал-демократизм, Институт истории партии, методологический плюрализм, марксистско-ленинская методология.

Для цитирования: Белозорович В. А. Борьба с национал-демократическим течением в белорусской историографии // Труды БГТУ. Сер 6, История, философия. 2021. № 1 (245). С. 68-73.

\section{A. Belazarovich \\ Yanka Kupala State University of Grodno \\ THE STRUGGLE WITH THE NATIONAL-DEMOCRATIC OVER IN BELARUSIAN HISTORIOGRAPHY}

The article reveals the process of approval of Marxist-Leninist methodology in the historical science of the BSSR in the 1920s -1930s under the influence of socio-political changes in Soviet society. The historiographical analysis of scientific works prepared by national-oriented Belarusian historians is carried out. The role of the Institute of party history and the October revolution under the Central Committee of $\mathrm{CP}(\mathrm{b}) \mathrm{B}$ as a methodological center for the struggle for "purity" of historical views is shown. The departure of a number of researchers, in particular, A. G. Chervyakov and D. F. Zhilunovich, from national positions in assessing the history of Belarus is revealed.

The research is based on historiographical sources of literary character, presented in the form of book production and publications in periodicals. Among them are works by Y. I. Lesik, A. L. Bourbis, F. F. Turuk, P. V. Trempovich, C. J. Wolfson, D. M. Vasilevsky and others. Also studied non-fiction ideological orientation - publications S. H. Agurskogo, A. I. Stalevicha, A. Sienkiewicza, and others.

The conclusion is made about the radical change of the methodological paradigm in historical cognition, manifested in the transition from the research pluralism of the 1920 s to the unanimity of the 1930s.

Key words: historiography, national democracy, Institute of party history, methodological pluralism, Marxist-Leninist methodology.

For citation: Belazarovich V. A. The struggle with the national-democratic over in Belararusian historiografhy. Proceedings of BSTU, issue 6, History, Philosophy, 2021, no. 1 (245), pp. 68-73 (In Russian).

Введение. Институт истории партии и Октябрьской революции, созданный при Центральном комитете Коммунистической партии (большевиков) Белоруссии, развернул борьбу с белорусскими национальными историками, взгляды которых трактовались как националдемократические.

Основная часть. В ходе белорусизации в БССР вернулись из эмиграции многие деятели белорусского национального движения, среди них - Цвикевич А. И., Ластовский В. Ю., Смолич А. И. и др. Их взгляды на историю белорусского народа обладали определенной спецификой. Подходы белорусской национальной 
историографии 1920-х гг. можно представить следующими концептуальными положениями: теория «единого потока», теория незрелости классовых противоречий в белорусской нации, теория «двухкоренности» образования КП(б)Б, теория четырех общественных групп, положение о ведущей роли интеллигенции в революционных процессах, понимание национального самосознания народа как главного фактора исторического процесса.

Эти положения нашли отражение в статьях сборника «Беларусь: очерки истории, экономики, культурного и революционного движения» (1924) [1]. И. Ю. Лёсик в статье «Культурное положение Беларуси к моменту Февральской революции» [1, с. 100-118] утверждал, что крестьянский характер белорусской нации сложился исторически. Буржуазные слои общества экономически и культурно были оторваны от народных масс. Обособленность крестьянства стала проявляться в XVI в., когда часть крестьян-слуг приняла польский язык и польскую культуру [1, с. 100]. Автор статьи доказывал наличие «белорусской шляхты». Он утверждал, что «белорусское шляхетство - самое типичное белорусское население. Шляхтичи сохранили белорусские культурно-национальные традиции [1, с. 101]. Корни белорусской шляхты И. А. Лёсик видел в панцирных и путных боярах, которые эволюционировали в т. н. «застенковую» и «околичную» шляхту. $\mathrm{K}$ XX в. они сохранили свою обособленность от крестьянства, но самостоятельно вели земледельческое хозяйство и поголовно сохранили белорусский дедовский уклад жизни [1, с. 103].

А. Л. Бурбис в статье «Белорусская Социалистическая Громада в первый период ее деятельности (1903-1907)» [1, с. 177-181] проанализировал предысторию белорусского национального движения до образования БСГ, осветил организационное становление партии, акцентировав внимание на социалистическом характере программных документов [1, с. 179].

В 1923 г. была опубликована монография Ф. Ф. Турука «Белорусское движение: Очерк истории национального и революционного движения белорусов» [2]. Книга представляет собой первый научный анализ белорусского национального движения как явления общественно-политической жизни Беларуси. Автор лаконично охарактеризовал истоки белорусского национального движения, его развитие в начале XX в. Корни белорусского движения автор видел в ВКЛ и повторил идею М. В. Довнар-Запольского о цивилизационном влиянии Запада и Востока на белорусов [2, с. 6]. Историк выделил этапы белорусского движения: 1) «пробуждение интереса к ... местному народ- ному творчеству и быту» студентов Виленского университета; 2) попытки восстановления белорусской письменности писателями и учеными польского происхождения; 3) призыв к совместной борьбе с царизмом польских повстанцев; 4) деятельность народников; 5) кружковый период студенческой молодежи; 6) оформление белорусской политической партии [2, с. 8-18].

Революционные события 1917 г. историк проанализировал на основе теории четырех классово-национальных групп. По его мнению, у белорусов совпадали национальные и классовые интересы [2, с. 29-32]. Ф. Ф. Турук назвал ошибки, допущенные национальным движением: избрание Р. А. Скирмунта главой БНК, раскол на два течения белорусского движения [2, с. 36-37]. Историк не одобрил разгон Всебелорусского съезда 1917 г. [2, с. 40], считал неудачной попытку белорусских «незалежников» создать БНР в условиях немецкой оккупации. Образование БССР было для него «подлинно новым годом в жизни белорусских трудящихся масс» [2, с. 49].

В 1925 г. ассистент БГУ Тремпович П. В. в статье «Пути белорусской интеллигенции» поставил вопрос о сотрудничестве белорусской интеллигенции с КП(б)Б. По его мнению, старая белорусская интеллигенция, которая сформировалась в период «Нашей нивы», положила начало белорусскому возрожденческому движению, заложила основы белорусской государственности и культуры [3, с. 2-3].

Белорусские национальные историки разрабатывали проблематику истории революционного движения в Беларуси. С. Я. Вольфсон в статье «"Чорны перадзел” у Менску» подробно раскрыл деятельность данной организации [4]. В журнале «Полымя» были опубликованы воспоминания о событиях 1905-1907 гг. известного народовольца Бонч-Осмоловского А. И. [5]. Д. М. Василевский в статье «Беларускі нацыянальна-рэволюцыйны рух на Віцебшчыне ў XIX сталецьці» [6] впервые отнес Яна Борщевского и Яна Чечота к представителям белорусской литературы, осудил ликвидацию униатской церкви, которая сохраняла элементы белорусской культуры. Местная интеллигенция лишь во второй половине XIX в. проявила интерес к белорусскому народу [6, с. 125-131].

Событиям революции 1905-1907 гг. посвящены воспоминания А. А. Сенкевича. Автор доказывал наличие революционного аграрного движения на территории Беларуси, привел пример забастовки батраков в имениях Щорсы и Мир [7, с. 106], обратил внимание на деятельность «белорусского сознательного учительства», которое сформировало свой первый профессиональный союз в 1906 г. на съезде, состоявшемся у д. Николаевщина [7, с. 107]. 
Сотрудник Инбелкульта Шлюбский А. О. на материалах из Рукописного отдела Белорусской государственной библиотеки описал случаи конфискации полицией номеров газеты «Наша нива» в 1907 и 1915 гг. Автор составил хронологический перечень первых белорусских газет и журналов [8, с. 185], проанализировал программу БСГ 1906 г., текст которой сохранился в Гродненском губернском жандармском управлении, и указал на ее близость к позиции большевиков [9]. А. О. Шлюбский дал ответ на вопрос, кто был инициатором издания «Нашей доли» И. Луцкевич и А. Пашкевич [10]. Выпускник Дерптского университета Имшеник Ф. П. обозначил значение «Нашей нивы» для развития белорусского национального движения [11, с. 63]. Ход революционных событий 1917 г. исследовал Л. Коган. По его мнению, социальный состав населения Беларуси в начале XX в. включал четыре общественные группы [12, с. 84-85]. БСГ являлась левой партией, близкой по программе к большевикам, а КП(б)Б создали «заброшенные сюда случайно, войной и революцией, труженики из старой большевистской гвардии Москвы, Ленинграда, Иваново-Вознесенска» [12, с. 86-88]. Вопросы национальной политики затронул В. И. Пичета. Историк показал нетрадиционный подход к освещению предыстории белорусского национального движения, считал польское восстание 1863 г. толчком «хождения в народ». Изучение белорусского языка, этнографии и народной литературы позволило сделать вывод о самостоятельности белорусского народа $[13$, c. 144]. Большинство публикаций Д. Ф. Жилуновича было посвящено становлению белорусской советской государственности. В статье «Два бакі беларускага руху» [14] проводится идея ведущей роли БСГ в белорусском национальном движении $[14$, с. 69], теория двухкоренности КП(б)Б [14, с. 72]. Статья «Уступамі да Акцябра» посвящена формированию БСГ в Петрограде в период февраля - июня 1917 г. [15]. Д. Ф. Жилунович подробно описал первый день Съезда белорусских национальных организаций в Минске 25-27 марта 1917 г. [16].

С конца 1920-х гг. к национальной интеллигенции стали применяться репрессивные меры. Начинается кампания по борьбе с «нацдемовщиной». С. Х. Агурский в феврале 1929 г. выступил на XII съезде КП(б)Б с критикой оценки, данной В. М. Игнатовским восстанию 1863 г., доказывая, что восстание носило помещичьеклерикальный характер. В статье «Национал-демократические тенденции на историческом фронте Беларуси» («Пролетарская революция», № 8) позиция В. М. Игнатовского и Д. Ф. Жилуновича была определена как националистическая $[17$, c. $204-205]$.
Первостепенная роль в борьбе с националдемократизмом на историческом фронте принадлежала журналу «Большевик Беларуси». В № 3 за 1928 г. была опубликована статья А. Киржница «В неволе буржуазного национализма». В предисловии автор обозначил свое отношение к белорусскому национальному движению «националистическое движение», «соглашательская интеллигенция». Белорусское национальное движение А. Киржниц рассматривал на примерах Октябрьской революции и Всебелорусского съезда [17, с. 205].

В этом номере журнала представлена статья А. И. Столевича (Родевича) «Аб вытоках беларускага нацыянал-дэмакратызму i нацыяналфашызму». Автор отметил, что главной опасностью в БССР является белорусский националдемократизм, представители которого, будучи «агентурой польского фашизма», ведут работу среди крестьян и мелкой буржуазии [18, с. 17]. Истоки национал-демократизма А. Столевич видел в БСГ и «Нашей ниве» [18, с. 19-21].

А. Некрашевич в статье «Белорусский национал-фашизм и его собрат белорусский национал-демократизм» поставил на одну ступень «польский фашизм и белорусский националфашизм». Белорусское национальное движение возникло не на классовой, а на национальной основе. Фактором, активизировавшим национал-демократизм, стала аграрная политика наркома земледелия Д. Ф. Прищепова. Автор заострил внимание на основных положениях национал-фашизма: отрицание классовой борьбы в деревне и признание самобытности Беларуси.

На XII съезде КП(б)Б было заявлено, что белорусская национальная интеллигенция проводит националистический курс и растет за счет кулачества. Представители белорусского национального движения подвергли себя самокритике. Д. Ф. Жилунович направил в бюро ЦК КП(Б)Б письмо «Мае памылкі и их карэньні» (1929), в котором назвал БСГ «неоформленной и политически неопределенной полусектантской группой», а Всебелорусский съезд - «враждебной демонстрацией к рабоче-крестьянской власти». Историк себя критиковал за игнорирование классового принципа.

Член ЦК КП(б)Б Червяков А. Г. признал ошибочными свои взгляды на процесс построения социализма в БССР, осудил Д. Ф. Жилуновича за допущенные «ошибки», в частности за положительную оценку деятельности А. И. Луцкевича. А. Г. Червяков стремился лично отмежеваться от содержания статьи «Пявец барацьбы і барацьбіт за Савецкую Беларусь» (1928), посвященной 20-летию литературной деятельности Д. Ф. Жилуновича, в которой он представил Тишку Гартного «старым нашенивцем- 
возрожденцем», разбившим единый национальный антисоветский фронт.

Автор отказался от ранее предложенной им оценки «Нашей нивы» и Всебелорусского съезда 1917 г. Газета была названа идеологической трибуной белорусской буржуазии, а съезд признан контрреволюционным. Так как Д. Ф. Жилунович пропагандировал Октябрьскую революцию как крестьянскую («прышла ад цяжкіх сох»), А. Г. Червяков настаивал на пролетарском, социалистическом характере событий октября 1917 г. [19].

Идеологическая составляющая общественной жизни в БССР активно нарастала. К XIII съезду КП(б)Б (1930) официально объявили о ликвидации «прищеповщины» как проявления правой опасности. Сопротивление классовых врагов процессу социалистического строительства было представлено выступлением белорусских национал-демократов - «агентов белорусских национал-фашистов» [20, с. 116]. Они пропагандировали теорию самобытности белорусской культуры и чистоты родного языка. Второй опасностью назвали великодержавный русский шовинизм, препятствовавший осуществлению «пролетарского руководства широкими крестьянскими массами в БССР» [20, с. 117]. Объектом широкомасштабной критики стало выступление доцента БГУ И. В. Волк-Леоновича - автора языковой теории, согласно которой приоритетным является наречие, присущее доминирующей в обществе группе. Поскольку в БССР социальным гегемоном выступал пролетариат, то основу белорусского языка должен был составить язык горожан («испорченный белорусизмами русский язык»). Подобное заявление воспринималось как выступление против партийной национальной политики [20, с. 118].

В конце того же года заведующий агитационно-пропагандистским отделом ЦК КП(б)Б Сенкевич А. А. в статье «За ленінскую лінію ў нацполітыцы» [21] проанализировал все имеющиеся «искажения» партийной политики в национальном вопросе, которые прямо или косвенно затрагивали представления о прошлом белорусского народа. Тем самым общественному мнению предлагались готовые формы восприятия действительности. Отказ в признании самостоятельности белорусского языка со стороны ряда преподавателей БГУ и Белорусской сельскохозяйственной академии, уже известная позиция И. В. Волк-Леоновича воспринимались как антипартийное выступление [21, c. 160-161].

А. А. Сенкевич обратил внимание на активизацию еврейского и польского шовинизма. Он перечислил «ошибочные» теории, проповедуемые среди еврейского населения. Это поло- жение о единой, но угнетаемой еврейской нации; о еврейском национализме как реакции на антисемитскую политику русского самодержавия; о стремлении «очистить» еврейский язык от советизмов и интернационализмов; об отрицании классовых противоречий среди евреев; о идеализации Бунда и др. Синагоги воспринимались как «центры шовинистической деятельности среди еврейских трудящихся». Польские шовинисты были обвинены в национальной ограниченности, в ориентации на «фашистскую Варшаву» [21, с. 163].

В статье повторяется официальная позиция по делу «Союза освобождения Беларуси»: его участники стремились возродить буржуазную государственность в форме БНР, планировали соединить ее с Литвой и Украиной под властью «фашистской Польши». Прозвучало обвинение в идеализации истории: белорусскую культуру сформировали не «средневековые монахи» (Ф. Скорина и др.), а Октябрьская революция 1917 г.; XVI в. Нельзя считать Белорусским Ренессансом; не следует возносить в ранг национальных героев К. Калиновского и Ф. Богушевича. Автор статьи четко обозначил направление исторического развития Беларуси - в сторону «красной» Москвы, а не «культурного» Запада [21, c. 164-165].

Национал-демократы, выступавшие «за реставрацию капитализма в БССР», представляли собой в основном беспартийную массу. Но примкнувших к ним членов КП(б)Б А. А. Сенкевич отнес к национал-оппортунистическому направлению. Их идеология базировалась на ряде теоретических положений, схожих с нацдемовскими: единство белорусской нации, идеализация отечественной истории, преувеличение значения мелкобуржуазных партий, признание за интеллигенцией ведущей роли в революционных процессах, игнорирование пролетарского содержания национальной культуры, та же ориентация на «культурный» Запад [21, с. 166-169].

Сотрудник Института истории партии Зюзьков А. И. в брошюре «Крывавы шлях беларускай нацдэмократыі» (1931) дал характеристику «белорусской контрреволюции» в 1917 1921 гг., эволюции национал-демократизма в национал-фашизм [22, с. 3]. Автор использовал источники, поступившие на хранение в партийный архив республики - документы из архива БНР. Историк первым из белорусских советских исследователей написал о действиях С. Н. Булак-Булаховича [22, с. 39-40]. В итоге А. И. Зюзьков сформулировал три вывода: 1) национал-демократы никогда не стремились к самостоятельной БНР; 2) национал-демократы «грешили» политическим авантюризмом; 3) только пролетарская революция под руководством 
коммунистической партии могла решить национальный вопрос [22, с. 52-53].

Заключение. Таким образом, в 1920-е 1930-е гг. происходят радикальные изменения в развитии белорусской историографии. Завершился период методологического плюрализма, когда историческое познание осуществлялось представителями различных дореволюционных центров и направлений. Утратила значение национальная историография. Утвердилась марксистско-ленинская концепция отечественной истории.

\section{Список литературы}

1. Беларусь: нарысы гісторыі, эканомікі, культурнага і рэвалюцыйнага руху / пад агульнай рэд. А. Сташэўскага [і інш.]. Менск: ЦВК БССР, 1924. 322 с.

2. Турук Ф. Белорусское движение: Очерк истории национального и революционного движения белорусов. Минск: Картогр. ф-ка Белгеодезии, 1994. 144 с.

3. Трамповіч П. Шляхі беларускае інтэлігэнцыі // Савецкая Беларусь. 1925. 21 окт. (№ 239). С. 2-3.

4. Вальфсон С. «Чорны перадзел» у Менску // Полымя. 1925. № 4. С. 75-81.

5. Бонч-Асмалоўскі А. Эпоха 1905 г. Мае ўспаміны // Полымя. 1925. № 6. С. 176-201; № 7. C. $115-137$.

6. Васілеўскі Д. Беларускі нацыянальна-рэволюцыйны рух на Віцебшчыне ў XIX сталецьці // Полымя. 1925. № 5. С. 121-131.

7. Сянкевіч А. Успаміны з рэвалюцыі 1905-1906 г. // Полымя. 1923. № 3-4. С. 106-108.

8. Шлюбскі А. Да гісторыі конфіскацыі «Нашай Нівы» // Полымя. 1925. № 4. С. 185-189.

9. Шлюбскі А. Да гісторыі БСГ // Полымя. 1925. № 5. С. 157-163.

10. Шлюбскі А. Новыя матэрыялы да гісторыі «Нашае долі // Полымя. 1927. № 3. С. 199-205.

11. Імшэньнік Хв. «Наша Ніва» і дваццацігадовы юбілей беларускае пэрыодычнае прэсы // Полымя. 1926. № 7. С. 51-64.

12. Каган Л. Люты - кастрычнік на Беларусі // Полымя. 1925. № 7. С. 82-93.

13. Пічэта У. Формы нацыянальнага й опозыцыйнага руху на Беларусі // Полымя. 1924. № 2. C. $142-162$.

14. Жылуновіч 3. Два бакі беларускага руху // Полымя. 1923. № 3-4. С. 69-71.

15. Жылуновіч 3. Уступамі да Акцябра // Полымя. 1923. № 5-6. С. 141-148.

16. Жылуновіч 3. Зьезд беларускіх нацыянальных організацый. 25 сакавіка 1917 г. // Полымя. 1925. № 6. C. 202-206.

17. Белазаровіч В. А. Гістарыяграфія гісторыі Беларусі: дапаможнік па аднайменным курсе для студэнтаў. Гродна: ГрДУ, 2006. 345 с.

18. Сталевіч А. Аб вытоках беларускага нацыянал-дэмакратызму і нацыянал-фашызму // Бальшавік Беларусі. 1929. № 10-12 (кастрычнік - снежань). С. 17-32.

19. Чарвякоў А. Бальшавіцкай самакрытыкай выкрыем свае памылкі і яшчэ больш загартуем свае рады для барацьбы за сацыялізм // Звязда. 1929. 27 снеж. (№ 296). С. 2.

20. Беднарскі С. На гістарычным павароце (Аб ітогах XVI зьезду ЎсеКП(б) і XIII зьезду КП(б)Б) // Полымя. 1930. № 8. С. 103-135.

21. Сянькевіч А. За ленінскую лінію ў нацполітыцы // Полымя. 1930. № 11-12. С. 159-175.

22. Зюзькоў А. Крывавы шлях беларускай нацдэмократыі / Ін-т гісторыі партыі і Кастрычніцкай рэвалюцыі пры ЦК КП(б)Б. Менск: Белдзяржвыд., 1931. 86 с.

\section{References}

1. Stasheuski A., Zhilunovich Z., Ignatouski V. Belarus': narysy gistoryi, ekanomiki, kul'turnaga i revalyutsyynaga rukhu [Belarus: essays on the history, economy, culture and the revolutionary movement]. Minsk, TsVK Publ., 1924. 322 p.

2. Turuk F. Belorusskoye dvizheniye: Ocherk istorii natsional'nogo i revolyutsionnogo dvizheniya belorusov [Belarusian movement: an essay on the history of the national and revolutionary movement of Belarusians]. Minsk, Kartogr. f-ka Belgeodezii Publ., 1994. 144 p.

3. Trampovich P. Ways of the Belarusian intelligentsia. Savetskaya Belarus' [Soviet Belarus], 1925, no. 239, pp. 2-3 (In Belarusian).

4. Val'fson S. "Black Redistribution" in Minsk. Polymya [Flame], 1925, no. 4, pp. 75-81 (In Belarusian).

5. Bonch-Asmalouski A. The epoch of 1905 in my memoirs. Polymya [Flame], 1925, no. 6, pp. 176201; no. 7, pp. 115-137 (In Belarusian).

6. Vasileuski D. Belarusian national revolutionary movement in Vitebsk region in the 19th century Polymya [Flame], 1925, no. 5, pp. 121-131 (In Belarusian). 
7. Stankevich A. Memories of the revolution of 1905-1906 years. Polymya [Flame], 1923, no. 3-4, pp. 106-108 (In Belarusian).

8. Shlubski A. To the history of confiscation of "Our Field". Polymya [Flame], 1925, no. 4, pp. 185189 (In Belarusian).

9. Shlyubski A. On the history of the Belarusian socialist community. Polymya [Flame], 1925, no. 5, pp. 157-163 (In Belarusian).

10. Shlyubski A. New materials for the history of "Our Share". Polymya [Flame], 1927, no. 3, pp. 199-205 (In Belarusian).

11. Imshen'nik F. Nasha Niva and the twentieth anniversary of the Belarusian periodical press. Polymya [Flame], 1926, no. 7, pp. 51-64 (In Belarusian).

12. Kagan L. February-October in Belarus. Polymya [Flame], 1925, no. 7, pp. $82-93$ (In Belarusian).

13. PichetaV. Forms of national and opposition movement in Belarus. Polymya [Flame], 1924, no. 2, pp. 142-162 (In Belarusian).

14. Zhylunovich, Z. Two sides of the Belarusian movement. Polymya [Flame], 1923, no. 3-4, pp. 69-71 (In Belarusian).

15. Zhylunovich Z. Steps to October. Polymya [Flame], 1923, no. 5-6, pp. 141-148 (In Belarusian).

16. Zhylunovich Z. Congress of Belarusian national organizations. March 25, 1917. Polymya [Flame], 1925 , no. 6, pp. 202-206 (In Belarusian).

17. Belazarovich V. A. Istoriografiya istorii Belarusi [Historiography of the history of Belarus: manual for students]. Grodno, State University of Grodno Publ., 2006. 345 p.

18. Stalevich A. About the origins of Belarusian national-democracy and national-fascism. Bal'shavik Belarusi [Bolshevik of Belarus], 1929, no. 10-12, pp. 17-32 (In Belarusian).

19. Bednarski S. At a historical turn. Polymya [Flame], 1930, no. 8, pp. 103-135 (In Belarusian).

20. Stankevich A. For the Leninist line in national politics. Polymya [Flame], 1930, no. 11-12, pp. 159-175 (In Belarusian).

21. Zyuz'kov A. Kryvavy shlyakh belaruskay natsdemokratyi [The bloody path of the Belarusian nationaldemocracy]. Mensk, Beldzyarzhvyd. state Publ., 1931. 86 p.

\section{Информация об авторе}

Белозорович Виктор Александрович - кандидат исторических наук, доцент, декан факультета истории, коммуникации и туризма. Гродненский государственный университет имени Янки Купалы (230023, г. Гродно, ул. Ожешко, 22, Республика Беларусь).E-mail: vbelozorovich@mail.ru

\section{Information about the author}

Belazarovich Viktar Aleksandrovich - PhD (History), Associate Professor, Dean Faculty of History, Communication and Tourism. Yanka Kupala State University of Grodno (22, Ozheshko str., 230023, Grodno, Republic of Belarus). E-mail: vbelozorovich@mail.ru 